\title{
EFFECT OF EGG STORAGE PERIOD ON THE IMMUNITY AND THE HATCHED DUCKLING'S PERFORMANCE
}

\author{
A. A. El-Fiky, A. A. Enab, S. A. Abd El-Rahman, M. F. Hussein \\ Dept. of poultry and Fish Production, faculty of Agric., Menoufia Univ., Egypt.
}

Received: Apr. 21, 2020

Accepted: May. 30,2020

\begin{abstract}
This study was conducted at the French Group Company at Al-Sadat City in Menoufia Governorate. The hundred forty-eight fertile eggs were collected from 200 females of Pekin ducks (Anas platyrhynchos) at the age of (26 weeks of production), which mated by artificial insemination with $\mathbf{3 0}$ male of Muscovy ducks (Cairina moschata) to produce Molar ducks. Eggs were divided into four equal treatments (each of 96 eggs) and subjected to different storage periods $(0,4,8$ and 12 days) to determine the effects of different storage periods on egg weight loss, hatchability, hatch window, duckling quality, duckling immunity, and its body weight were measured for the different treatments. The results revealed that there were insignificantly differences $(p \leq 0.05)$ in egg weight loss by the different preincubation egg storage period. Storage eggs for 0 days had the highest hatchability percentage $(92.2 \%)$ compared to other experimental groups. Data demonstrated that storage eggs for 12 days achieved the largest hatch window (17:30 hours) when compared with 0,4 and 8 days of storage. The relationship between storage period and duckling quality revealed that storage eggs for 0 days achieved the highest quality compared to the other groups. Immunity also, was affected by storage period ( 0 days was the highest immunity) compared with the other groups. The effect of storage period on duckling body weight at age of one day was also studied. Data indicated that third group (storage periods 8 days) achieved significantly $(P \leq 0.01)$ highest body weight $(76 \mathrm{~g})$. It could be concluded that storage of fertile duck eggs should not exceed 8 days to avoid excessive loss of egg water that impair the albumen contents which needed by the developing embryo for growth during incubation. The storage also, affected the transfer of maternal immunity to the embryos and the hatched ducklings.
\end{abstract}

Key words: Molar ducks, storage periods, hatchability eggs, duckling quality, immunity.

\section{INTRODUCTION}

Pre-incubation egg storage is a necessity for the poultry industry, where it is a common hatchery practice mostly due to the imbalance between hatching egg supply from the breeding farms and the demand for day old chicks from the broiler farms.

The length of storing period varies between a few days and several weeks because it depends on the hen's egg production, maximum hatchery capacity and both the demand and fluctuating prices of one day old chicks in the market (Reijrink et al., 2010). Storing length had impact on embryonic viability and hatchability (Fasenko, 2007 and Bakst et al., 2012). Fasenko et al. (2011) found that hatching eggs of most poultry species stored for over 7 days had harmful effects on hatchability. For this, numbers of strategies have been investigated to improve hatchability of eggs stored for more than seven days; one of them is to incubate eggs before storage.

Abdel-Hack et al. (2019) demonstrated that many factors are related to fertility and hatching, such as environmental conditions, production system, season, 
nutrition, management of brood stock and storage time.

The quality of day-old chicks is the uppermost preference in the minds of most poultry managers. Among different chick quality measurement methods, either quantitative or qualitative, chick weight, a quantitative method is the most widely used indicator for day-old chick quality assessment (Deeming, 2000 and Decuypere, et al., 2002). There are many factors that affect chick weight and ultimate chick quality in broiler breeders such as egg weight and quality. The egg size is important because of its direct relationship (Moran, 1990) or positive correlation (Wilson and Suarez, 1993; Seker et al., 2004 and Lourens et al., 2006) with the size of the day-old chick, which comprises about $64-70 \%$ of the weight of the egg.

The objective of this study was to consequently the effect of different egg storage periods on some hatching parameters and body weight curve. Also, to study its effect on the immunity of new natal ducklings' quality and consequently on its body weight curve.

\section{MATERIALS AND METHODS}

This study was conducted at the French Group Company, Al-Sadat City, Menoufia Governorate. The experiment was extended from 21 March 2018 to 7 June 2018, to investigate the effect of different pre-incubation eggs storage period on the egg weight loss, hatchability, hatch window, duckling quality, duckling immunity and its body weight.

\section{Mating system:}

By using artificial insemination, a total number of $\mathbf{3 8 4}$ fertile eggs were collected from 200 females Pekin ducks, Anas platyrhynchos, at the age of (26 weeks of production) reared in floor pens under standard husbandry conditions which mated by artificial insemination with $\mathbf{3 0}$ male of Muscovy ducks, Cairina moschata, to produce Molar ducking's. Fertile eggs (384) were randomly randomly divided into four equal treatments (each of 96 eggs) and subjected to different storage periods ( 0 , 4, 8 and 12 days). Eggs collected every four days before noon and subjected to cleaning and disinfectants, then punctuation and weighed and placed (on the small end down) repeatedly on a cooling cabined at $18^{\circ} \mathrm{C}$ and $75 \%$ humidity.

The traditional temperatures used for all incubators were $37.25{ }^{\circ} \mathrm{C} \pm 0.05$ dry bulbs during the incubation period (0 - 28 d) and $37{ }^{\circ} \mathrm{C}$ dry bulbs during the hatching period $(28-31$ d). The traditional $\mathrm{RH}$ was $31-32.5^{\circ} \mathrm{C}$ wet bulb from 0 to $28 \mathrm{~d}$ and $32-36^{\circ} \mathrm{C}$ wet bulb from 28 to $31 \mathrm{~d}$.

As was standard commercial industry practice, all eggs were removed from the incubators for cooling at $18 \mathrm{~d}$ for $15 \mathrm{~min}$. twice daily from 18 to $28 \mathrm{~d}$ of incubation. Eggs were turned every $1 \mathrm{~h}$ to $28 \mathrm{~d}$ of incubation. At $28 \mathrm{~d}$ of incubation, the eggs were candled, and those with evidence of living embryos were transferred individually into hatching baskets and then placed into hatchers for the remainder of incubation.

At $31 \mathrm{~d}$ of incubation (hatching day), ducklings that had fully emerged from their shells were removed and weighed.

\section{Housing and feeding of birds:}

Pekin females duck were exposed to 18 hours of light, while Muscovy males were exposed to 16 hours during mating.

After hatching Molar duckling were reared in floor pens and brooded under 24 hours of light during the first and second week. From the beginning of the third week the number of hours of light was reduced by an hour to 16 hours. 
All Molar duckling were fed ad libitum a starter diet (containing 20\% CP and $2904 \mathrm{ME} \mathrm{Kcal} / \mathrm{Kg}$ diet) until 21 days of age and grower diet (containing $18 \%$ CP and $2970 \mathrm{ME} \mathrm{Kcal} / \mathrm{Kg}$ diet from 22 to 35 days of age (Table1).

\section{Studied traits were as follows:}

\section{1. Egg weight loss: -}

Egg weight every day by using a balance for nearest (1 $\mathrm{g})$. Eggs are placed and stored in a cooling unit at 18 ${ }^{\circ} \mathrm{C}$ and $75 \%$ humidity, to study the effect of increasing egg storage periods on the rate of moisture loss from eggs.

\section{2. Hatchability:}

Eggs were incubated in an automatic incubator and hatching performance was recorded. Treated groups are examined each week to determine the effect of the storage period on early and dead embryos at different hatching stages.

At the end of the hatch, the hatched eggs showing stickiness and pips were counted separately as dead in shell. At $24^{\text {th }}$ day of incubation, the eggs were candled. The embryo of hatching eggs showing the evidence of retarded development on candling were considered as dead embryos, which were subsequently confirmed by the broken examination. At $31^{\text {st }}$ day of incubation the healthy duckling were removed and recorded.

Hatchability was calculated as number of healthy ducklings hatched divided number fertile of eggs as follows:

Hatchability $\%$ = no. of hatched ducklings $\times 100 /$ no. of fertile eggs.

Table 1. Composition and calculated analysis of the commercial diets fed during starting $(1-21)$ and growing periods (22 - 35) days of age.

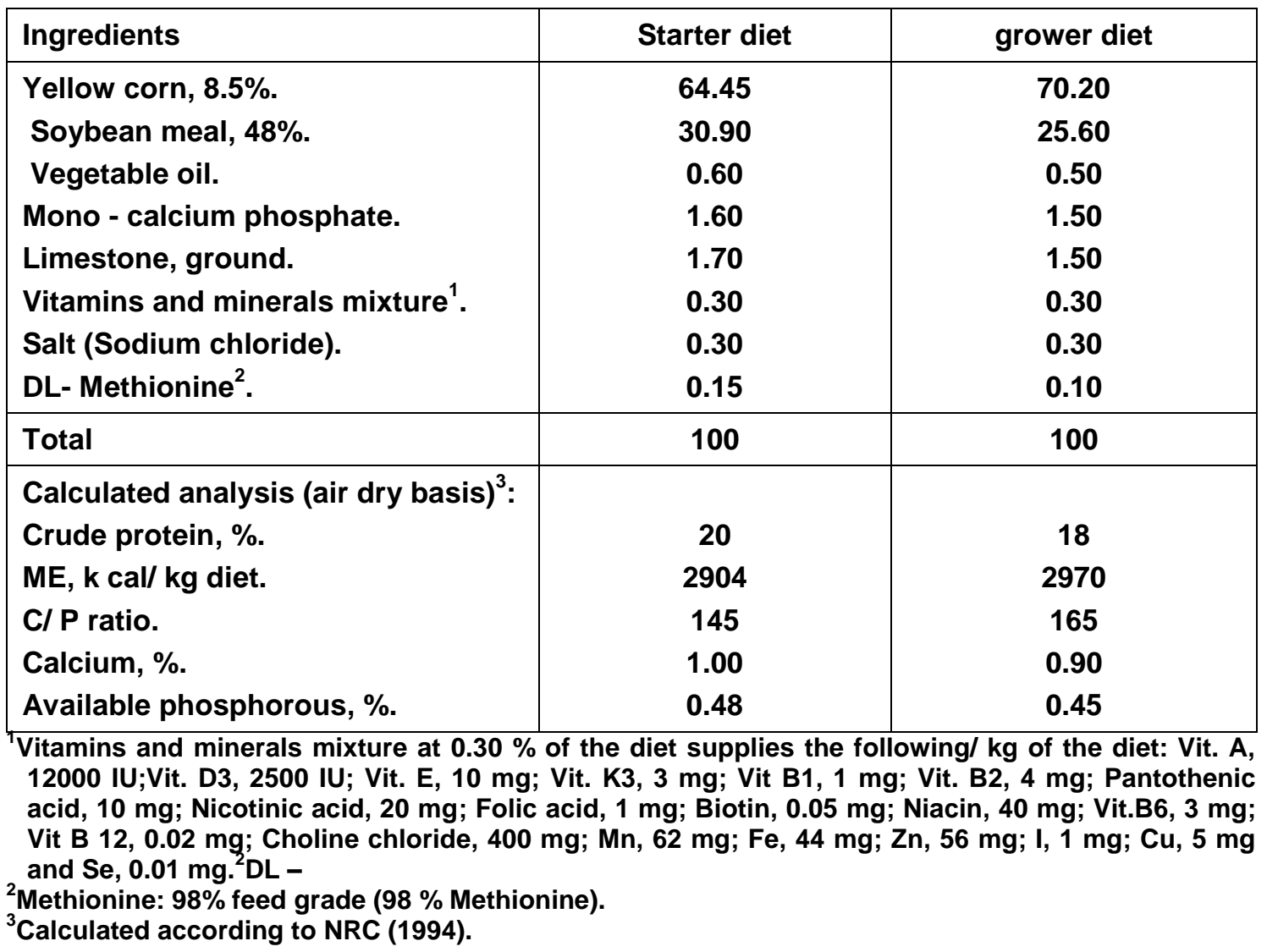




\section{3. Hatch window:}

The hatch window is considered a management tool in modern commercial hatcheries. The definition of nature hatch window (H. W.) is the time that it takes the chicks to hatch in an ideal incubation environment. Hatch window was determine the time span between the hatching of the first and last chick.

\section{4. Duckling quality:}

After calculating hatchability and hatch window, the quality assays of the ducklings are evaluated to study the effect of storage period on duckling quality. Duckling quality is defined to encompass several qualitative characteristics and scored according to their importance. Quality usually correlated to relative growth rate and storage period. After hatch, duckling removed from the hatcher and that showed defect in structure, size, shape feathering and other abnormalities like, lameness and blindness were recorded and considered as abnormal ducklings. A duckling of good quality is defined as being clean, dry and free from deformities (no skin lesions, well-formed beak, normal legs and completely sealed navel).

The percentage of ducklings with quality score of $\mathbf{1 0 0}$ (healthy ducklings).

That activity is assessed by laying the duck on its back to determine how quickly it returned to its feet. A quick spring back into its feet was regarded as good, but trailing back into its feet or remaining on its back was assessed as weak the control has achieved the highest activity compared to $(4,8$ and 12 d).

Appearance, the duck's body was examined for dehydration, hygiene and any defects in the navel, legs or eyes. It was considered natural if it was dry, clean and free from other defects, if it is wet, dirty or weak (which can be a source of pollution), this is not good.

The eyes, the duck were put on the legs, and its eyes were observed. The state of brightness and wideness of the gape of the eyelids were estimated, the control and 4 days recorded the largest number in the amplitude of the eye.

Legs, the duck were put on its feet to determine if it remained upright well. The toes were examined for their conformation. If the duck remained upright with difficulty, articulations of the knees were examined to detect signs of inflammation or redness or both.

Navel area, navel and surrounding areas were examined for closure of the navel and its coloration. If the color was different from the skin color of the duck, then it was regarded as bad.

\section{5. Determination of antibody response:}

The primary antibody titers to SRBCs were determined for all individuals as the following steps:

\section{5. 1. Preparation of sheep red blood cells antigen:}

The sheep red blood cells (SRBC) were chosen as natural, nonspecific, non-pathogenic and multi-determinant immunizing antigen to elicit the antibody response in the ducks (Kundu et al., 1999). The SRBC were obtained in a heparin solution from Ossimi sheep breed and washed three times in phosphate buffer saline (PBS, Ph. 7.2). After final wash, the packed SRBC were brought to a $2.5 \% \mathrm{Vo} / \mathrm{Vo}$ solution in the PBS and used for immunization.

\section{5. 2. Antigen immunization:}

The SRBC antigen was immunized using a slight modification in the method of Siegel and Gross (1980). The primary immune response in both sexes (female 
Pekin and Muscovy males) was estimated at 26 weeks of production, whereas immunity was assessed for the Molar ducks at 6 days after hatching. The individual antibody response was determined for each individual at 7 days after immunization. All duck veins were inoculated by arterial vein with a $0.1 \mathrm{ml}$ suspension of $2.5 \%$ SRBC suspension to induce initial antibody response.

\section{5. 3. Blood samples collection and serum preparation:}

Ducks were bled from the wing vein at 7 days post immunization. Before drawing blood samples, the syringes were washed with a heparin solution to prevent clotting. About $2-3 \mathrm{ml}$ of blood was taken from each bird. Serum was collected, placed in disposable tubes and frozen for subsequent laboratory analysis.

\section{5. 4. Titration and calculation of antibody titers:}

The antibody in the duck's blood sera were determined by the microtiter method of hemagglutinin test assay described by Siegel and Gross (1980). Serum samples were titrated individually in 96- well (eight rows by 12 columns, round (U) bottom) assay plates. Only, 50 $\mu \mathrm{l}$ of physiological saline $(0.9 \% \mathrm{Na} \mathrm{Cl})$ was added to all 96 - well plates followed with $50 \mu \mathrm{l}$ of serum sample to first well (row 1). Serial dilutions of each serum sample were then made from the first through the eleventh wells. This step results in dilutions ranging from $1: 1$ to 1:1024. Well number 12 was used as the control. Next, $50 \mu$ of $2.0 \%$ packed SRBC solution was added to each well. The 96well plates were then covered, mixed and incubated at $37{ }^{\circ} \mathrm{C}$ for about one hour. Then, both variables, positive and negative hemagglutination, were recorded. Antibody titers were expressed as the $\log _{2}$ of the reciprocal of the last serum dilution, in which there was positive complete hemagglutination.

\section{6. Body weight:}

Growth rate percentage was calculated for each duckling's weekly during the periods from hatch - 1, 1 - 2, 2 $-3,3-4$ and $4-5$ weeks of age using the following formula (Brody, 1945).

$\begin{aligned} \text { Growth rate }(\%)= & \left(W_{2}-W_{1}\right) \times 100 / 0.5\left(W_{2}\right. \\ & \left.+W_{1}\right)\end{aligned}$ Where:

$W_{1}=$ the first weight and $W_{2}=$ the second weight.

\section{7. Statistical analysis:}

Least square means and their standard errors $(X \pm S E)$ for each studied trait were calculated for each group. Data obtained were statistically analyzed using SPSS (2011). Probability value, ( $P \leq$ 0.05) was considered for significant. All percentages data were converted to the corresponding arcsine prior statistical analysis as given by SAS (1988). Duncan's multiple range test was used for the multiple comparisons of means (Duncan, 1955).

One-way classification statistical fixed model was used for statistical analysis as follows:

Where:

$$
Y_{i j}=\mu+G_{i}+e_{i j}
$$

$Y_{i j}=$ the observation of the individual over all means,

$\mu=$ the common mean,

$G_{i}=$ the fixed effect of egg storage, and

$e_{i j}=$ the experimental random error.

\section{RESULTS AND DISCUSSION}

\section{Effect of storage period on the pre-incubation egg weight loss:}

In domestic avian species, eggs were stored at cool temperature until they can be placed into an incubator. The low temperature, induced diapause enables the embryo to survive until optimal 
temperature and humidity of the incubation condition can be provided to support embryonic growth.

Data from Table 2 demonstrated that, storage egg for 4,8 , and 12 days those stored when compared with 0 days significant differences $(p \leq 0.05)$ in egg weight loss during storage.

These results were in agreement with those obtained by Jones, and Musgrove (2005) and Alpay and Petek (2016). Who stated that, egg weight loss during the storage period significantly $(p \leq 0.05)$ affected by length of storage period.

Egg weight loss as a percentage of initial egg weight during storage period was significantly affected by storage length.

\section{Effect of storage period on hatchability of ducks:}

There are significant effects of storage periods on hatchability. At the cellular level, long term egg storage induces cell death. This appears to be occurring both via necrosis and apoptosis. The result is higher embryonic mortality and consequently lower hatchability.

It is clear from Table 3 that, the storage eggs for 0 days has achieved the highest percent of hatchability of fertile eggs $(92.2 \%)$ when compared with eggs stored for 4,8 , and 12 days.
Also, the hatchability percent decreased sharply after $8^{\text {th }}$ day of storage.

These results were in agreement with those obtained by Alpay and Petek (2016) and Liang yuan, et al. (2017).

They stated that prolonged periods of egg storage are usually accompanied by a number of negative consequences on embryonic development, hatching, and post hatch chick quality and performance. In general, hatchability was more affected by length of egg storage period and it is recommended to store ducks' eggs for a period not more that 8 days. Hatchability of eggs stored for long period (11 d) was significantly lower, as a result of lower quality of the albumen and also increased embryonic death. (Onbasilar et al, 2006).

\section{Relationship between egg storage period and hatch window:-}

Hatch window defind as the time between early hatched and late hatching chicks. It was found that increasing the length of the storage period affects the hatch window. Recent studies demonstrated that, physiological differences exist between early and late hatching chicks. Early hatched chicks found to be less developed than later hatched chicks at the end of hatch window.

Table 2. Effect of egg storage period ( $\bar{x} \pm S E$ ) on the pre-incubation egg weight loss.

\begin{tabular}{|c|c|c|c|c|}
\hline $\begin{array}{c}\text { Storage period } \\
\text { (days) }\end{array}$ & $\begin{array}{c}\text { no. of } \\
\text { eggs }\end{array}$ & $\begin{array}{c}\text { Egg weight } \\
(\mathrm{g})\end{array}$ & $\begin{array}{c}\text { Egg weight loss. } \\
(\%)\end{array}$ & $\begin{array}{c}\text { p. value } \\
(\text { Sig. })\end{array}$ \\
\hline Control $(0$ days) & 96 & $87.49 \pm 0.58$ & $0.00^{\mathrm{d}}$ & \multirow{2}{*}{$0.05^{\star}$} \\
\hline 4 days & 96 & $87.19 \pm 0.57$ & $0.34^{\mathrm{c}}$ & \\
\hline 8 days & 96 & $86.95 \pm 0.58$ & $0.64^{\mathrm{b}}$ & \\
\hline 12 days & 96 & $86.51 \pm 0.60$ & $1.12^{\mathrm{a}}$ & \\
\hline
\end{tabular}

a, b, c, d: Means in the same column bearing different superscripts are significantly different. *= significant $(p \leq 0.05)$. 
Table 3. Effect of egg storage period $\left(\bar{x}_{ \pm}\right.$SE) on hatchability (\%) of ducklings.

\begin{tabular}{|c|c|c|c|c|c|}
\hline \multirow{2}{*}{ Item } & \multicolumn{4}{c|}{ Treatments } \\
\cline { 3 - 6 } & $\begin{array}{c}\text { Control } \\
\text { (0 days) }\end{array}$ & 4 days & 8 days & 12 days \\
\cline { 3 - 6 } & $\begin{array}{c}\text { Of total } \\
\text { eggs }\end{array}$ & 86.4 & 84.3 & 82.2 & 76 \\
\cline { 2 - 6 } $\begin{array}{c}\text { Hatchability } \\
\%\end{array}$ & $\begin{array}{c}\text { Of fertile } \\
\text { eggs }\end{array}$ & 92.2 & 92 & 87.7 & 85.8 \\
\hline
\end{tabular}

Data from Table 4 demonstrated that, storage egg for 12 days achieved the largest hatch window (17:30 hours) when compared with 0,4 , and 8 days of storage. (11:30, 11:30 and 12:40 hours, respectively).

These results were in agreement with those obtained by Yalcin. et al. (2016). Who stated that, mixing eggs from different storage period affects the hatch spread, which is referred to 12 to $48 \mathrm{~h}$ of hatch window (Decuypere et al., 2001 and Careghi et al., 2005). This means that the time spent in the incubator from hatching to pulling is longer for early hatched than late hatched chicks.

Whereas these results were in disagreement with those obtained by Tona, et al. (2003), who stated that the spread of hatch was not affected by storage time $(P=0.69)$.

\section{Relationship between egg storage period and quality of hatched ducklings: -}

Chick quality was defined to encompass several qualitative characteristics and scored according to their importance. Pre-incubation egg storage, it is usually accompanied by a number of negative consequences on embryonic development, hatching, and post hatch chick quality and performance.
Data from Table 5 proved that, storage egg for 0 days achieved highest quality ( 77 healthy ducks) compared to 4,8 , and 12 days of storage $(71,75$ and 62 respectively). Results generally indicate that, egg storage has negatively affected quality methods.

These results were in agreement with those obtained by Tona, et al. (2003) and Onbasilar, et al. (2007).

Ishaq, et al, (2015) demonstrated that, higher average chick weight was observed in one- and four-days storage than that of seven days storage in all production phases. They stated also that, higher chick percent in one- and fourdays storage was observed than that of seven days.

The percentage of ducklings with quality score of 100 (healthy ducklings) was lower in eggs stored for 12 days and the highest value achieved in the control group.

Results in Table 5 showed that activity is assessed by laying the duck on its back to determine how quickly it returned to its feet. A quick spring back into its feet was regarded as good, but trailing back into its feet or remaining on its back was assessed as weak the control has achieved the highest activity compared to $(4,8$ and $12 \mathrm{~d})$. 
A. A. El-Fiky, et al.,

Table 4. Effect of egg storage period $\left(\bar{X}_{ \pm} \mathrm{SE}\right)$ on hatch window of the duckling.

\begin{tabular}{|c|c|c|c|c|}
\hline \multicolumn{1}{|c|}{ Item } & \multicolumn{4}{|c|}{ Treatments } \\
\hline & Control (0 days) & 4 days & 8 days & 12 days \\
\hline Hatch window & $11: 30$ hour & $11: 30$ hour & $12: 40$ hour & $17: 30$ hour \\
\hline
\end{tabular}

Table 5. Effect of egg storage period on quality of ducklings.

\begin{tabular}{|l|c|c|c|c|}
\hline \multirow{2}{*}{ Items } & \multicolumn{4}{c|}{ Treatments } \\
\cline { 2 - 5 } & $\begin{array}{c}\text { Control } \\
\text { (0 days) }\end{array}$ & 4 days & 8 days & 12 days \\
\hline \% Vitality. & 98 & 85 & 80 & 80 \\
\hline $\begin{array}{l}\text { no. of the healthy } \\
\text { duckling. }\end{array}$ & 77 & 71 & 75 & 62 \\
\hline no. of weak ducklings. & 6 & 10 & 4 & 11 \\
\hline no. of unhealed navels. & 1 & 3 & 5 & 9 \\
\hline no. of malformed leg. & Zero & 1 & 3 & 4 \\
\hline Feather color. & light yellow & yellow gold & yellow gold & dark yellow \\
\hline Drought feathers. & dry & dry & $\begin{array}{c}\text { wet some } \\
\text { thing }\end{array}$ & $\begin{array}{c}\text { more } \\
\text { hydrated }\end{array}$ \\
\hline \multirow{2}{*}{ The eyes bright. } & $\begin{array}{c}77 \text { ducks } \\
\text { eyes wide }\end{array}$ & $\begin{array}{c}77 \text { ducks } \\
\text { eyes wide }\end{array}$ & $\begin{array}{c}76 \text { ducks } \\
\text { eyes wide }\end{array}$ & $\begin{array}{c}62 \text { ducks } \\
\text { eyes wide }\end{array}$ \\
\cline { 2 - 6 } & $\begin{array}{c}6 \text { ducks } \\
\text { eyes } \\
\text { narrow }\end{array}$ & $\begin{array}{c}4 \text { ducks eyes } \\
\text { narrow }\end{array}$ & $\begin{array}{c}9 \text { ducks } \\
\text { eyes narrow }\end{array}$ & $\begin{array}{c}11 \text { ducks } \\
\text { eyes narrow }\end{array}$ \\
\hline
\end{tabular}

Appearance, the duck's body was examined for dehydration, hygiene and any defects in the navel, legs or eyes. It was considered natural if it was dry, clean and free from other defects, if it is wet, dirty or weak (which can be a source of pollution), this is not good.

The eyes, the duck were put on the legs, and its eyes were observed. The state of brightness and wideness of the gape of the eyelids were estimated, the control and 4 days recorded the largest number in the amplitude of the eye. As the egg storage period increases (12 d), the number of ducks with narrows eyes increases 11 compared to 6 duckling in control group.
Legs, the duck were put on its feet to determine if it remained upright well. The toes were examined for their conformation. If the duck remained upright with difficulty, articulations of the knees were examined to detect signs of inflammation or redness or both, as the egg storage period increases (12 d), the number of ducks with malformed leg increases ( 4 duckling) as compared with 0 duckling in the control group.

Navel area, navel and surrounding areas were examined for closure of the navel and its coloration. If the color was different from the skin color of the duck, then it was regarded as bad, as the egg storage period increases, the number of 
ducks with unhealed navels (9) for 12 days storage compared with (1 duckling) for control ones ( 0 day storage).

\section{Effect of egg storage period (days) on the immunity concentration:}

Newly hatched birds are initially protected from infections by maternal antibodies present in the egg yolk. Dayold chicks possess a functional but na"ive immune system and must therefore be immunized to raise protective immune responses against major pathogens.

Table 6 demonstrated that the effect of egg storage period on immunity of hatched ducklings. Data revealed that, there were highly significant differences $(P \leq 0.001)$ between treatments in the immunity concentration, where the 4-d storage period achieved the highest concentration of immunity (9.34 lu $/ \mathrm{ml})$ when compared with $12 \mathrm{~d}$ group (2.53 lu (ml).

These results were in disagreement with those obtained by Goliomytis, et al., (2015) who stated that, length of egg storage period did not affected humeral response to SRBC
Beginning at the time of laying, the initial protective structures of the egg, the biomineralized eggshell, egg-white antimicrobial peptides, and vitelline membrane, are rapidly and dramatically altered during embryonic development.

Transfer of maternal immunity in birds is a two-storage process. Firstly, low levels of antibodies are transferred to the yolk as it develops and at oogenesis, then there is a sudden influx of antibodies and other yolk components in the last few days prior to egg formation and laying.

Table 7 illustrated that concentration of immunity of both parents. It is obvious that, concentration of immunity in Muscovy males was higher $(8.16 \mathrm{lu} / \mathrm{ml})$ than that of pekin female $(6.72 \mathrm{lu} / \mathrm{ml})$. The relative amount of antibodies transferred to offspring can vary significantly and consistently between females.

Ismoyowati (2013), stated that percentage transfer of maternal antibody titer for Muscovy hens (60.69) to egg yolk (45.87) and to offspring (30.47). Level of maternal antibody started to increase at 14. 19 days to hatch and Igy transfer rate sharply increased from egg yolk to the embryos blood circulation.

Table 6. Effect of egg storage period $(\bar{x} \pm \mathrm{SE})$ on immunity of ducklings.

\begin{tabular}{|c|c|c|c|c|}
\hline \multirow{2}{*}{ Items } & \multicolumn{4}{|c|}{ Treatments } \\
\cline { 2 - 5 } & $\begin{array}{c}\text { Control } \\
\text { (0 days) }\end{array}$ & 4 days & 8 days & 12 days \\
\hline no. of ducks. & 10 & 10 & 10 & 10 \\
\hline Immunity (lu/ ml). & $9.29^{\mathrm{a}} \pm 0.66$ & $9.34^{\mathrm{a}} \pm 0.52$ & $4.47^{\mathrm{b}} \pm 0.25$ & $2.53^{\mathrm{c}} \pm 0.14$ \\
\hline $\begin{array}{c}\text { Change of control } \\
\text { (\%) }\end{array}$ & 100.00 & 100.55 & 48.17 & 27.2 \\
\hline P. value (Sig.) & & \multicolumn{3}{|c|}{$0.001^{\star \star \star}$} \\
\hline
\end{tabular}

$a, b, c:$ Means in the same row bearing different superscripts are significantly different $* *=$ highly significant $(p \leq 0.01)$. 
A. A. El-Fiky, et al.,

Table 7. The immunity concentration (lu/ml) of the parents of the experimental group.

\begin{tabular}{|c|c|c|}
\hline The parents & $\begin{array}{c}\text { no. of } \\
\text { ducks }\end{array}$ & $\begin{array}{c}\text { Antibody titer } \\
(\bar{X} \pm \mathrm{SE})\end{array}$ \\
\hline Dam (pekin) & 10 & $6.72 \pm 0.78$ \\
\hline Sire (Muscovy) & 10 & $8.16 \pm 0.73$ \\
\hline
\end{tabular}

The transfer of antibodies from mother to offspring is key to protecting young animals from diseases and can have a major impact on responses to infection and offspring fitness.

Maternal antibodies are transferred from the mother via egg yolk to offspring until they are 2 wks. In birds, immunity transfer can have direct effects on offspring growth rate. This may be due to passively protecting the hatched chicks from common pathogens before their endogenous immune system has matured.

Table 8 demonstrated that concentration of immunity of both parents and offspring. It is obvious that, concentration of immunity in parents was higher $(7.44 \mathrm{lu} / \mathrm{ml})$ than that of offspring (6.40 lu/ml).

\section{Effect of egg storage period on duck's body weight at 1-day of age.}

Data from Table 9 the storage egg for 8 days and 12 days achieved the largest chick B.W $\quad(76.00$ and $72.56 \mathrm{~g}$ respectively) compared to 4 and 0 days of storage $(70.06$ and $70.00 \mathrm{~g}$, respectively).

These results were in agreement with those obtained by Tona, et al., (2003 and 2004) and Onbasilar, et al., (2007).

Sözcü and Ipek (2018) reported that results showed that a longer storage period caused a decline in yolk absorption and therefore decline of embryo growth parameters including body weight and length during incubation period. Egg weight loss increased with increased storage length $(P \leq 0.01)$, and the chick weight tended to decline in relation with storage period longer than 5 - 7 days.

Ishaq, et al, (2015) reported that, length of storage period significantly $(P \leq$ 0.05) influenced the average chick weight.

This may due to the reduction of the hatch window for the stored eggs 0 and 4 days, which led to the hatching of these periods first and the continuation of these two treatments in the hatchery for the end of the remaining transactions of hatching this has lost some weight to the ducklings.

\subsection{Effect of egg storage period on ducks body weight at age of one week.}

Data from Table 10 demonstrated that, storage egg for 0 days achieved the heaviest weight chick B.W (158.57 g) when compared with 4,8 , and 12 days of storage (153.15, 151.25 and137.29 g). The difference was highly significant $(P \leq$ 0.001).

These results were in disagreement with those obtained by Onbasilar, et al. (2007) and Tona, et al. (2003 and 2004). They stated that on effects of storage egg were detected in BW or feed intake at 7-day after hatch. Goliomytis et al. (2015) also demonstrated that, egg storage did not have any effect on BW at 7 days. 
Table 8. Effect of egg storage on the immunity concentration $(\mathrm{lu} / \mathrm{ml})$ of both of parents and offspring.

\begin{tabular}{|c|c|c|}
\hline Items & $\begin{array}{c}\text { no. of } \\
\text { ducks }\end{array}$ & $\begin{array}{c}\text { Antibody titer } \\
(\bar{X} \pm \text { SE })\end{array}$ \\
\hline parents & 20 & $7.44 \pm 0.22$ \\
\hline progeny & 40 & $6.40 \pm 0.54$ \\
\hline
\end{tabular}

Relative amount of antibodies transferred to offspring vary significantly and consistently between different storage periods.

Table 9. Effect of egg storage period $(\bar{X} \pm S E)$ on ducks body weight at age of one day.

\begin{tabular}{|c|c|c|c|c|}
\hline \multirow[t]{2}{*}{ Items } & \multicolumn{4}{|c|}{ Treatments } \\
\hline & $\begin{array}{l}\text { Control } \\
\text { ( } 0 \text { days) }\end{array}$ & 4 days & 8 days & 12 days \\
\hline no. of ducks. & 22 & 22 & 22 & 22 \\
\hline Body weight (g). & $70.00 \pm 1.47^{b}$ & $70.06 \pm 0.99^{b}$ & $76.00 \pm 1.22^{a}$ & $72.56 \pm 1.32^{a b}$ \\
\hline $\begin{array}{c}\text { Change of control } \\
(\%) .\end{array}$ & 100.00 & 100.09 & 108.57 & 103.66 \\
\hline P. value (Sig.). & \multicolumn{4}{|c|}{$0.004^{\star \star}$} \\
\hline
\end{tabular}

a, b, c: Means in the same row bearing different superscripts are significantly different.

$* *=$ highly significant $(p \leq 0.01)$.

Table 10. Effect of egg storage period ( $\bar{x} \pm \mathrm{SE}$ ) on ducks body weight at age of one week.

\begin{tabular}{|c|c|c|c|c|}
\hline \multirow{2}{*}{ Items } & \multicolumn{4}{|c|}{ Treatments } \\
\hline & $\begin{array}{l}\text { Control } \\
\text { (0 days) }\end{array}$ & 4 days & 8 days & 12 days \\
\hline no. of ducks. & 22 & 22 & 22 & 22 \\
\hline Body weight (g). & $158.57 \pm 2.96^{a}$ & $153.15 \pm 3.95^{\mathrm{a}}$ & $151.25 \pm 3.16^{\mathrm{a}}$ & $137.29 \pm 3.54^{b}$ \\
\hline $\begin{array}{c}\text { Change of control } \\
(\%) .\end{array}$ & 100.00 & 96.58 & 95.38 & 86.58 \\
\hline P. value (Sig.). & \multicolumn{4}{|c|}{$0.001^{\star *}$} \\
\hline
\end{tabular}

a, b, c: Means in the same row bearing different superscripts are significantly different.

$* *=$ highly significant $(P \leq 0.01)$.

Whereas Sözcü and Ipek (2018) showed that, longer storage period. Caused a decline in yolk absorption and therefore decline of embryo growth parameters including BW. Whereas Onbasilar et al. (2007) stated that, weight of ducklings at $7 \mathrm{~d}$ and relative growth rate were higher in eggs stored for 0 and $3 \mathrm{~d}$ than in eggs stored for $7 \mathrm{~d}$. They recommended that; storage period should be no longer than $7 \mathrm{~d}$ for duck eggs. 


\subsection{Effect of egg storage period on ducks body weight at age of two weeks.}

Data from Table 11 demonstrated that, storage egg for 0 days achieved the heaviest chick B.W (460.75 g) when compared with 4,8 and 12 days of storage (453.23, 451.36 and 439.45 , respectively), but the difference was not significant.

These results were in agreement with those obtained by Tona, et al., (2003 and 2004) and Onbasilar, et al., (2007). They illustrated that, chick weight during the first 2 wk of age was not affected by the storage time.

\subsection{Effect of egg storage period on ducks body weight at age of 3 weeks.}

Data from Table 12 demonstrated that, storage egg for 0 days achieved the largest weight chick B.W (948.05 g) when compared with 4,8 and 12 days of storage (923.50, 922.00 and 915.41, respectively), but the differences were not significant.

These results were in agreement with those obtained by Tona, et al., (2003 and 2004) and Onbasilar, et al., (2007). They indicated that, at the end of third week, chicks from fresh eggs were heavier than those from eggs stored for $7 \mathrm{~d}$, and these differences increased until $42 \mathrm{~d}$.

Table 11. Effect of egg storage period $\left(\bar{X}_{ \pm} S E\right)$ on ducks body weight at age of 2 weeks.

\begin{tabular}{|c|c|c|c|c|}
\hline \multirow{2}{*}{ Items } & \multicolumn{4}{|c|}{ Treatments } \\
\hline & $\begin{array}{c}\text { Control (0 } \\
\text { days) }\end{array}$ & 4 days & 8 days & 12 days \\
\hline no. of ducks. & 22 & 22 & 22 & 22 \\
\hline Body weight (g). & $\begin{array}{c}460.75 \\
12.09^{\mathrm{a}}\end{array} \pm$ & $453.23 \pm 10.34^{a}$ & $451.36 \pm 1.47^{\mathrm{a}}$ & $439.45 \pm 9.33^{\mathrm{a}}$ \\
\hline $\begin{array}{c}\text { Change of control } \\
(\%) .\end{array}$ & 100.00 & 98.37 & 97.96 & 97.96 \\
\hline P. value (Sig.). & \multicolumn{4}{|c|}{$0.581 \mathrm{~N} . \mathrm{S}$} \\
\hline
\end{tabular}

a, b, c: Means in the same row bearing different superscripts are significantly different.

N.S = not significant.

Table 12. Effect of egg storage period $\left(\bar{x}_{ \pm S E}\right)$ on ducks body weight at age of 3 weeks.

\begin{tabular}{|c|c|c|c|c|}
\hline \multirow{2}{*}{ Items } & \multicolumn{4}{|c|}{ Treatments } \\
\cline { 2 - 5 } & $\begin{array}{c}\text { Control } \\
\text { (0 days) }\end{array}$ & 4 days & 8 days & 12 days \\
\hline no. of ducks. & 22 & 22 & 22 & 22 \\
\hline $\begin{array}{c}\text { Body weight } \\
\text { (g). }\end{array}$ & $948.05 \pm 19.41^{\mathrm{a}}$ & $923.50 \pm 20.61^{\mathrm{a}}$ & $922.00 \pm 18.14^{\mathrm{a}}$ & $915.41 \pm 12.71^{\mathrm{a}}$ \\
\hline $\begin{array}{c}\text { Change of } \\
\text { control (\%). }\end{array}$ & 100.00 & 97.41 & 97.25 & 96.56 \\
\hline P. value (Sig.). & \multicolumn{4}{|c|}{0.610 N. S } \\
\hline
\end{tabular}

a, b, c: Means in the same row bearing different superscripts are significantly different.

N.S = not significant. 


\section{4. Effect egg storage period on ducks body weight at age of 4 weeks.}

Data from Table 13 demonstrated that, storage egg for 0 days achieved the heaviest duckling B.W (1422.61 \pm 29.79) when compared with 4,8 , and 12 days of storage (1415.32, 1411.68 and 1284.05 , respectively). The differences were highly significant $(P \leq 0.003)$.

These results were in agreement with those obtained by Tona, et al., (2003 and 2004) and Onbasilar, et al., (2007).

\subsection{Effect of egg storage period on ducks body weight at age of 5 weeks.}

Data from Table 14 demonstrated that, storage egg for 0 days achieved the heaviest weight duckling B.W (1891.81 \pm 33.12) when compared with 4,8 and 12 days of storage (1761.29, 1753.57 and 1659.33, respectively). The difference was highly significant $(P \leq 0.001)$.

These results were in disagreement with those obtained by Tona, et al. (2003 and 2004) and Onbasilar, et al. (2007). They stated that, negative effect of egg storage on BW did not persist in post hatch performance as no effects of egg storage were detected in BW at 7 and $35 \mathrm{~d}$. This may be due to the relatively low correlation coefficients between BW at hatch and $35 \mathrm{~d}$.

Table 13. Effect of egg storage period $\left(\bar{X}_{ \pm S E}\right)$ on ducks body weight at age of 4 weeks.

\begin{tabular}{|c|c|c|c|c|}
\hline \multirow{2}{*}{ Items } & \multicolumn{4}{|c|}{ Treatments } \\
\cline { 2 - 5 } & Control (0 days) & 4 days & 8 days & 12 days \\
\hline no. of ducks. & 22 & 22 & 22 & 22 \\
\hline $\begin{array}{c}\text { Body weight } \\
\text { (g). }\end{array}$ & $1422.61 \pm 29.79^{\mathrm{a}}$ & $1415.32 \pm 30.38^{\mathrm{a}}$ & $1411.68 \pm 30.29 \mathrm{a}$ & $1284.05 \pm 27.58^{\mathrm{b}}$ \\
\hline $\begin{array}{c}\text { Change of } \\
\text { control (\%). }\end{array}$ & 100.00 & 99.49 & 99.23 & 90.26 \\
\hline $\begin{array}{c}\text { P. value } \\
\text { (Sig.). }\end{array}$ & \multicolumn{4}{|c|}{$0.003^{\star *}$} \\
\hline
\end{tabular}

$a, b, c:$ Means in the same row bearing different superscripts are significantly different.

$* *=$ highly significant $(p \leq 0.01)$.

Table 14. Effect of egg storage period $(\bar{X} \pm S E)$ on ducks body weight at age of 5 weeks.

\begin{tabular}{|c|c|c|c|c|}
\hline \multirow{2}{*}{ Items } & \multicolumn{4}{|c|}{ Treatments } \\
\cline { 2 - 5 } & $\begin{array}{c}\text { Control }(0 \\
\text { days) }\end{array}$ & 4 days & 8 days & 12 days \\
\hline no. of ducks. & 22 & 22 & 22 & 22 \\
\hline $\begin{array}{c}\text { Body weight } \\
\text { (g). }\end{array}$ & $1891.81 \pm 33.12^{\mathrm{a}}$ & $1761.29 \pm 36.60^{\mathrm{b}}$ & $1753.57 \pm 34.06^{\mathrm{b}}$ & $1659.33 \pm 29.98^{\mathrm{c}}$ \\
\hline $\begin{array}{c}\text { Change of } \\
\text { control (\%). }\end{array}$ & 100.00 & 93.10 & 92.69 & 87.71 \\
\hline P. value (Sig.). & \multicolumn{4}{|c|}{$0.001^{\text {*** }}$} \\
\hline
\end{tabular}

a, b, c: Means in the same row bearing different superscripts are significantly different. $* *=$ highly significant $(p \leq 0.01)$. 


\section{CONCLUSION}

The obtained results in the present investigation indicated that storage of fertile duck eggs should not exceed 8 days to avoid excessive loss of egg water that impair the albumen contents which needed by the developing embryo for growth during incubation, and obtaining adequate hatchability, favorable value of hatching window, good rate vitality of hatching ducklings and high quality of hatching ducklings. Prolonged egg storage periods affected the transfer of maternal immunity to the new natal duckling and consequently led to negative impact on its growth improving.

\section{REFERENCES}

Abdel-Hack, M. E., C. B. Hurtado, D. M. Toro and M. Alagawany (2019). Fertility and hatchability in duck eggs. Get Access Volume 75: 599 - 608.

Alpay, F. and M. Petek (2016). Effects of hatching egg weight and length of storage period on hatching success in pekin ducks. Journal of Biological and Environmental Sciences; 15 (28): 29 34.

Bakst, M. R., V. Akuffo, D. Nicholson and N. French (2012). Comparison of blastoderm traits from 2 lines of broilers before and after egg storage and incubation. Poultry Science., 91: 2645 - 2648.

Brody, S. (1945). Bioenergetics and growth. Reinhold pub. Cprp,. N. Y., USA.

Careghi, C., K. Tona, O. Onagbesan, J. Buyse, E. Decuypere and V. Bruggeman (2005). The effects of the spread of hatch and interaction with delayed feed access after hatch on broiler performance until seven days of age. Poultry Science, 84: 1314 1320.

Decuypere, E., K. Tona, V. Bruggeman and F. Bamelis (2001). The day-old chick, a crucial hinge between breeders and broilers. World's Poultry Science Journal, 57: 127 - 138.

Decuypere, E., K. Tona, F. Bamelis, C. Careghi, B. Kemps, B. De Ketelaere, J. De Baerdemaker and V. Bruggeman (2002). Broiler breeders and egg factors interacting with incubation conditions for optimal hatchability and chick quality. Arch. Geflugelkd, 66: 56 - 57.

Deeming, D. C (2000). What is chick quality? World Poultry, 11: 34 - 35.

Duncan, D.B. (1955). Multiple range and multiple f. Test Biometrics, 11:1.

Fasenko, G. M. (2007). Egg storage and the embryo. Poultry Science, 86: 1020 $-1024$.

Fasenko, G.M., L.L. Guan and D.R. Barreda (2011). Broiler egg storage induces cell death and influences embryo quality. Poultry Science, 90: $1749-57$.

Goliomytis, M., T. Tsipouzian and AL. Hager-Theodorides (2015). Effects of egg storage on hatchability, chick quality, performance and immunocompetence parameters of broiler chickens. Poultry Science, 94: 2257 - 2265.

Ishaq, H. M., M. Akram, M. E. Baber, A. S. Jatoi, A. W. Sahota, K. Javed, M. H. Jaspal, S. Mehmood, J. Hussain and F. Hussnain (2015). Chick quality of hubbard broiler breeders train with three different egg weights and storage periods at four production phases. JAPS, Journal of Animal and Plant Sciences, 25 (1): 37 - 44.

Ismoyowati, Eka Lestari and Sukardi Sukardi (2013). Korelasi antara bobot telur dengan bobot tetas dan perbedaan susut bobot pada telur entok (Cairrina Moschata) dan itik (Anas Plathyrhinchos). Jurnal IImiah Peternakan,

Jones, D. R. and M. T. Musgrove (2005). Effects of extended storage on egg quality factors. Science volume 84: 1770 - 1777. 
Kundu, A., D.P. Singh, S.C. Mohapatra, B.B. Dash, R.P. Moudgal and G.S. Bisht (1999). Antibody response to sheep erythrocytes in indian native vis-à-vis imported breeds of chickens. British Poultry Science. 40;1, 40-43.

Liangyuan, Wei, Su. Chinhui, Chen. Yengping, Liu. Hsiuchou, Chang. Chiaoying, Chang. Weibeng, Chang. Yiying and Huang. Jengfang (2017). Effects of storage time and age on fertility and mortality of hatching eggs for minimal disease white Muscovy duck. Journal of Taiwan Livestock Research, 50 (2): 96 - 102.

Lourens, A., R. Molenaar, H. Van Den Brand, M. J. Heetkamp, R. Meijerhof and B. Kemp (2006). Effectof egg size on heat production and the transition of energy from egg to hatchling. Poultry Science, 85: 770 - 776.

Moran, Jr, E.T. (1990). Effects of weight, glucose administration at hatch, and delayed access to feed and water on the poult at 2 weeks of age. Poult. Sci., 69: 1718-1723.

NRC, (1994). Nutrient requirements of poultry. 9th rev. ed. washington (dc): National Academy Press.n

Onbasilar, E. E., S. Yalcın, Z. Reisli and S. Yalcın (2006). Effect of garlic powder on the performance, egg traits and blood parameters of laying hens. J Sci Food Agric., 86: 1336 - 1339.

Onbasilar, E. E., O. Poyraz and E. Erdem (2007). Effects of egg storage period on hatching egg quality, hatchability, chick quality and relative growth in pekin ducks. Archiv Fur Geflugelkunde, 71(4): 187 - 191.

Reijrink, I. A. M., D. Berghmans, R. Meijerhof, B. Kemp and H. Van Den Brand (2010). Influence of egg storage time and preincubation warming profile on embryonic development, hatchability, and chick quality. 2010 Poultry Science, 89: 1225 - 1238.

SAS (1988). As the foundation for SAS analytics SAS/STAT provides state of the art statical analysis software that empowers you to make new discoveries. Science. 89: 259 - 279.

Seker, I., S. Kul and M. Bayraktar (2004). Effects of paternal age and hatching egg weight of japanese quails on hatchability and chick weight. Int. J. Poult. Sci., 3 (4): 259 - 265.

Siegel, P.B. and W.B. Gross (1980). Production and persistence of antibody response to sheep erythocytes. 1. Directional selection poultry Sci., 59 1-6.

Sözcü, A. and A. Ipek (2018). Increasing of storage period alters embryo development and hatching characteristics of pekin duck eggs. Agriculture and Forestry, 64 Issue 4: 65 - 70.

SPSS, (2011). PC. Programe by spss inc., North Michigan, US.A.

Tona, K., F. Bamelis, B. De Ketelaere, V. Bruggeman, V. M. B. Moraes, J. Buyse, O. Onagbesan and E. Decuypere (2003). Effects of egg storage time on spread of hatch, chick quality, and chick juvenile growth. Poultry Science, 82: 736 - 741.

Tona, K., O. Onagbesan, B. De Ketelaere, E. Decuypere and V. Bruggeman (2004). Effects of age of broiler breeders and egg storage on egg quality, hatchability, chick quality, chick weight, and chick posthatch growth to forty-two days. Journal of Applied Poultry Research, 13: 10 - 18.

Wilson, H. R. and M. E. Suarez (1993). The use of egg weight and chick weight coefficients of variation as quality indicators in hatchery management. J. Appl. Poult. Res., 2: 227 - 231.

Yalcin, S., I. Gurse, G. Bilgen, G. T. Izzetoglu, B. H. Horuluoglu and G. Gucluer (2016). Egg storage duration and hatch window affect gene expression of nutrient transporters and intestine morphological parameters of early hatched broiler chicks. Animal, 10 (5): 805 - 811. 
تأثير مدة تخزين البيض على مناعة وكفاءة صغار البط الفاقسة

عبد المنعم عبد الحليم الفقى، أحمد عبد الوهاب عنب، سبد عبد الفتاح عبد الرحمن، محمود فهمي حسين

قسم إنتاج الدواجن والأسماك - كلية الزراعة - جامعة المنوفية - شبين الكوم.

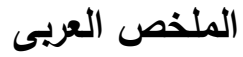

أجريت هذه التجرية في شركة المجموعة الفرنسية بمدينة السادات - محافظة المنوفية لاراسة تأثير فترات تخزين

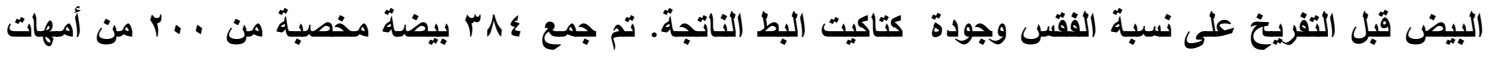

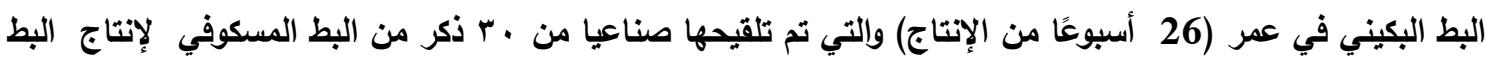

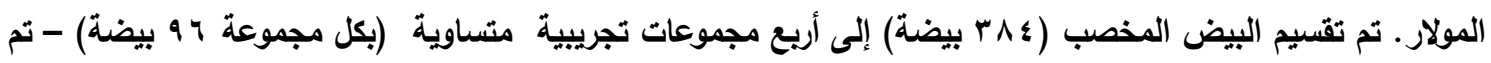
تخزينها لفترات مختلفة قبل التفريخ - فقد تم تخزين المجموعة الأولى (المقارنة) صفر يوم، والمجموعة الثانية خزنت لمدة

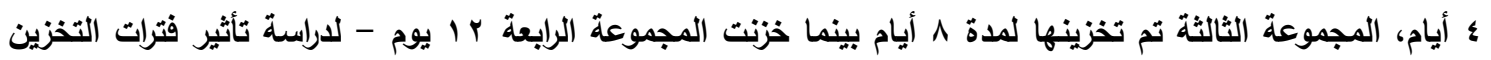

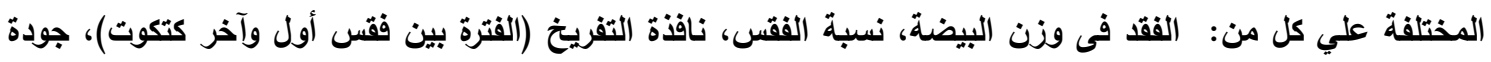

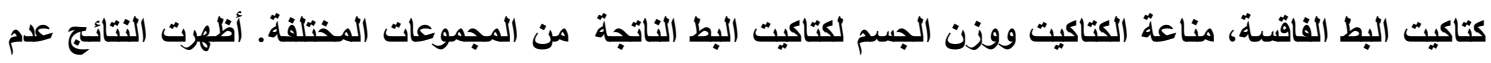

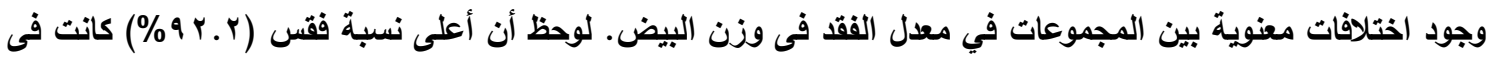

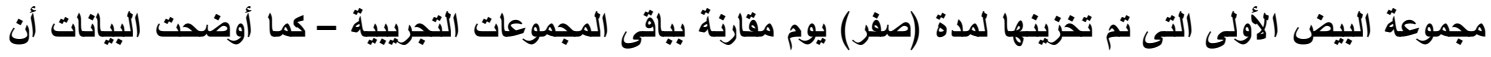

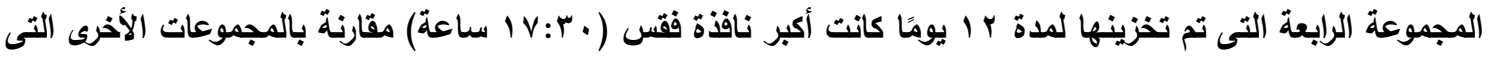
تم تخزينها لمدة صفر ، ؛ و 1 أيام . كما أظهرت النتائج أن أعلى جودة لكتاكيت البط الفاقسة كانت للمجموعة الأولى من البيض (الكتترول) التى تم تخزينها لمدة صفر يوم - تبين أيضا أن الكتاكيت الناتجة من المجموعة الأولى من البيض (الكنترول) التى تم تخزينها

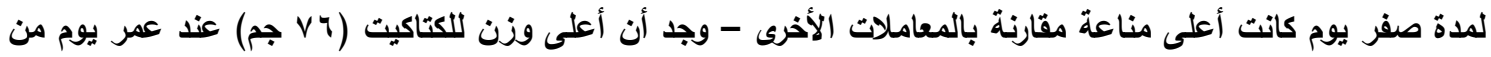

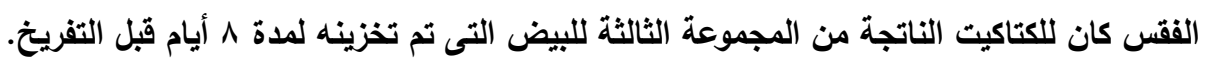

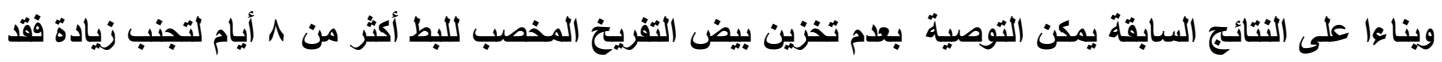

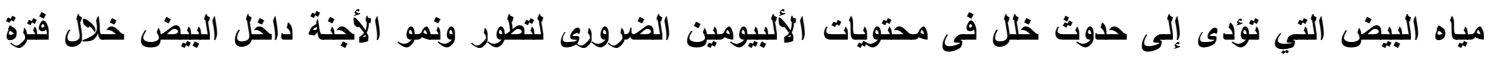

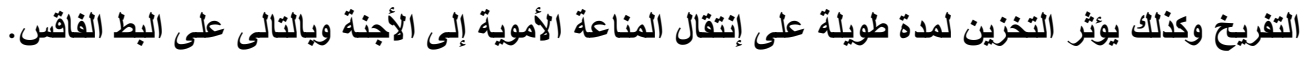
الكلمات المرشدة : البط المولار، فترة التخزين، بيض التفريخ، جودة الكتاكيت، الفقس، المناعة. 
Effect of egg storage period on the immunity and the hatched duckling's ............ 